\title{
A Critique of Aviation Management Programs
}

\author{
Edwin D. Phillips \\ Southern Illinois University Carbondale
}

\begin{abstract}
Periodic critique is a characteristic of successful organizations. This article uses the concepts of critical management research to describe and critique all University Aviation (UAA) Association aviation management bachelor degree programs. Narrative and tabular description is provided of the location, title, department administrative location in the university, mission and courses offered by UAA member schools. A brief history of the introduction and purpose of aviation management is offered. Critique is made regarding the lack of a clear definition of "aviation management," and that the technological attraction of aviation flight education may overshadow the role of aviation management education. Specific recommendations are made to improve the current state of aviation management programs.
\end{abstract}

\section{INTRODUCTION}

This article reviews and critiques aviation management bachelor degree programs at University Aviation Association (UAA) member colleges and universities in the United States. $\mathrm{UAA}$ is the preeminent professional organization for non-engineering aviation education at the college level. There is no evidence to suggest programs offered at nonUAA institutions have characteristics that differ from those of UAA member schools. Periodic critique is a key component of any successful organization (Blake and Mouton, 1985). My recent entry into the world of aviation management education following twenty-nine years of challenging and varied management experiences with a major airline is the motivating force for this critique.

This work is divided into four sections. The introduction provides a perspective for the research. The second part of the article is a narrative picture (taken in the year 2003) of aviation management programs identified by department title, name of degree(s) offered, where departments are administratively placed within a university, department mission and titles of courses offered. The third section is a critique that discusses these programs and the existence and interaction of various values within society in general and the aviation educational community in specific. The article ends with specific recommendations to improve the aviation management educational product.

\section{Audience}

The audience for this article is students, administrators, faculty, advisory board members and alumni involved in the process of providing aviation degree programs in the United States. No experience or expertise is claimed for programs located outside the United States and any such programs are excluded from the study. Some of the concepts discussed may have application to non-USA programs, but no such claim is made.

\section{Research Method}

People, humans, are the engine of aviation education. The individuals involved in producing aviation programs are practicing management, the principles of planning, organizing, leading and control (Daft \& Marcic, 2001). Study of aviation education practices is therefore the study of people, or social science. This requires qualitative research, the "understanding of subjective experience, meaning and intersubjective interaction" (Fossey, Harvey, McDermott, \& Davidson, 2002, p. 718) that occurs among the people who create, offer and modify aviation management degrees. The positivism of a statistical approach is inappropriate. Research practices of collecting and analyzing data for this project are specifically guided by the concepts of "naturalistic inquiry" as described by Lincoln and Guba (1985) and "critical management research” formed by Alvesson and Deetz (2000). 


\section{Defining “Critique”}

The reader may (and probably should) reflect on the meaning of "critique." Does this article intend to be "critical," and if so, in what manner? Research must be viewed on a continuum. Alvesson and Deetz (2000) indicate there are two aspects to critical management research. One is to view "critical" as a postmodern questioning of social order and dominating practices. The second is a focus on qualitative or interpretive research. This paper leans heavily toward the second perspective but does not ignore the first. Where appropriate an effort is made to "...counteract the dominance of taken-for-granted goals, ideas, ideologies and discourses which put their imprints on management and organization phenomena" (Alvesson and Deetz, 2000, p. 18.).

\section{Data Collection}

Today's electronic world makes data for this project accessible on UAA, the Council on Aviation Accreditation, and individual college and university web sites. Email inquiry and phone calls were used as necessary to clarify or expand web site information. Key aviation journals and published meeting proceedings were reviewed for related material.

\section{OVERVIEW OF AVIATION MANAGEMENT PROGRAMS}

\section{The Reason for Aviation Management Programs}

Consistent oral history and expressed belief among experienced members of the aviation academic community suggests that aviation management bachelor degree programs were created to meet pilot hiring requirements. At some point in history the major airlines began to prefer or demand pilot job applicants have a bachelor's degree in addition to the required pilot licenses and desired flight hours. Some colleges and universities which offered only flight training determined it was necessary to create a four-year degree to allow students to become highly desirable job applicants. "Aviation management" programs were the solution. Today these programs also serve the needs of non-pilot students who wish to learn about aviation business skills and the challenges faced by managers in consulting firms, airports, airlines, government agencies, etc.

\section{Number of Aviation Management Programs}

Mandis (1984) published the first listing of accredited colleges, universities and technical schools that offer aviation related programs. He listed 377 programs. Kaps (1995) indicated there were 351 associate, bachelor and certificate related non-engineering aviation programs. These numbers have historical value but include many programs beyond aviation management bachelor degrees.

The NewMyer, Kaps, and Sigler's (2001) review of Aviation Management programs includes 43 schools. Oderman (2003) states there are 60 aviation management or aviation administration programs in the United States. Neither report provides criteria for inclusion of programs reviewed in the research and may include other than UAA programs.

All 117 UAA member institutions were analyzed for this project. Those programs selected for inclusion offer a bachelors degree with emphasis on the conceptual and technical skills of managing and/or that are designed to prepare students for possible management positions. This encompasses programs in "corporate aviation," "airport," "air traffic control," "aviation administration" and or "aviation management." At the conclusion of the review a possible description suggested itself. "Aviation management" tends to encompass all aviation bachelor degree programs other than those with a primary emphasis on flight or maintenance. There are 56 UAA programs that meet these criteria. Based on Oderman's work and this research it is reasonable to conclude there are about 55 to 60 aviation management bachelor degree programs in the United States. Table 1 lists the names and key characteristics of the 56 UAA programs.

\section{Number of Degree Titles}

The 56 schools in this study offer degrees with 40 different titles. "Aviation management," the most common, is found at 18 schools. "Aviation administration," "airway science" and "airport management" degrees are each found at three schools. The other 36 titles are a variant on the four primarily used titles and 
include single use titles that vary from "Aeronautical Management Technology" to "Urban Policy Studies (specialization in aviation management).” A detailed list is included in Table 2.

\section{Aviation Management Department Administrative Positioning}

An understanding of the aviation management academic discipline is guided by how aviation departments are administratively placed within a university. A pattern of placing departments in any one or a particular combination of colleges may shed light on how academia views the discipline. Forty-five of the 56 departments are positioned within a "college" or "school" that most frequently includes other non-aviation departments.

Subtle name variations may indicate locally significant variance not clear from an outsider's perspective. Recognizing that possibility it appears that aviation management departments are placed in colleges or schools with 34 different titles. Six (18\%) are in business or management colleges. Table 3 lists the administrative locations.

\section{Department Mission}

The Council on Aviation Accreditation (CAA) requires accredited programs "MUST have a mission statement that reflects an educational philosophy, goals, purposes, and general intent..." (Council on Aviation Accreditation, 2003, p. 15). Reviewing departmental mission statements should provide the key direction or philosophy of a program. Six of the 56 UAA aviation management programs include a mission statement on the department's web site. They are:

- Delaware State University - Dover, Delaware

- Delta State University - Cleveland, Mississippi

- Elizabeth City State University - North Carolina

- Lynn University - Boca Raton, Florida

- Texas Southern University - Houston, Texas

- University of Maryland Eastern Shore Princess Anne, Maryland
The mission statement of these six departments emphasizes a mission of preparing students for jobs or careers in aviation. Elizabeth City State adds in a separate area that the educational objectives of the program include providing graduates “.... with the ability to develop clear and careful scientific reasoning; and to comprehend the sub-disciplines that influence the nation's aviation industry and systems” (Elizabeth State University, 2004, Aviation Science).

None of the six match the more universal theme of The Transportation Center at Northwestern University which is, "Since its inception in 1954, the Center's mission has been to make substantive and enduring contributions to the movement of materials, people, energy, and information" (Northwestern University, 2004, Northwestern University Transportation Center).

\section{Course Content}

What we do as individuals - or departments - are perhaps the true measure of what we think or feel. Reviewing courses offered in aviation management programs is therefore a meaningful indication of what is believed to be important. Judgments about specific course content based on title and catalog description is an inexact science. Recognizing that limitation, the diversity of course offerings is shown in Table 4. A total of 39 titles are offered. Of these, 18 are offered in only one or two of the 56 UAA programs. Some key courses that should be on the list are missing and identified later in this article.

\section{Defining “Aviation Management”}

The first aviation school in the United States is St. Louis University's Parks College of Engineering and Aviation which was founded in 1927 (St. Louis University, 2004). Flouris (2001) states that Auburn University's aviation management program was founded in 1941 and is the second-oldest in the country. Although aviation management has existed for over sixty years as a field of study there is mystery associated with a definition of the term. Efforts to identify the first aviation management program have been unsuccessful. 
The U.S. Department of Transportation (DOT) lists and explains common transportation "expressions." "Air Traffic Management (ATM)" is on the list and is defined as "The process used to ensure the safe, efficient, and expeditious movement of aircraft during all phases of operations. Air traffic management consists of air traffic control and traffic flow management” (Bureau of Transportation Statistics, 2004). “Aviation management” is not on the list. Articles that address some aspect of aviation management (Flouris, 2001; Worrels, 2002) often don't define what is meant by the term. A more critical issue is students say something like, "I'm an aviation management major, but I don't really know what that means." There is no central or common definition that resolves that question.

An early and highly popular Bill Cosby comedy routine includes dialog in which the teacher says, "Two and two is four." The child's response is, "What's a 'two"”? Don't those of us who are in field of aviation management education already know what "aviation management” is? Some may believe attempting to formalize a definition is akin to asking for a description of "two." It is an uncommon question or challenge. To build and use mathematical formulas knowing the construct of "two" is mandatory. To successfully educate students in aviation management it seems a logical conclusion that educators must have a clear understanding of what is described by that term.

Determining the philosophical construct of aviation management seems a mandatory step in a critique of aviation management bachelor degree programs. Without a clear understanding it is a messy, if not impossible, journey to the next logical step of identifying the pedagogy of aviation management. A meaningful pedagogy for the discipline of aviation management rests on a clear understanding (i.e. definition) of the term.

Efforts to clarify the term are not new. “...The problem with Aviation Management is that it does not have a clearly defined curricular content or structure" (Fairbairn, 1987, p.81). No specific definition of "aviation management" is found in the literature. To complicate matters, alternate terms "aviation administration" and "aviation science" are commonly used. An award winning ethics article uses the terms "aviation management" and "aviation administration" interchangeably in the same paragraph (Oderman, 2002, p. 6). A follow-up article uses the same dual reference on a single page (Oderman, 2003, p. 17.) "Aviation science" is a term used in eight difference degree titles.

NewMyer, Kaps, and Sigler (2001) completed a review of aviation management programs. The first section of their report presents "Aviation Management Definitions." The "definitions" are a list of eight statements from aviation department web pages that describe the program offered at that individual university. Most address the intent to prepare students for careers in aviation jobs. This suggests that "aviation management" is the process of preparing individuals for jobs in industry. Such a definition or description seems incomplete.

A definition of "aviation sciences" is found on the web pages of The University of Maryland Eastern Shore (UMES) Aviation Sciences Program. It states, "Aviation Sciences are the theory and practices of the technical skills required to perform professional services in the field of aviation" (UMES, 2004). This definition is noteworthy because its existence is unique.

Reviewing the Council on Aviation Accreditation's (CAA) standards manual provides solid data for consideration. The CAA (2003) lists aviation management as one of six degree specializations. A "Narrative Description" of "Option Criteria" indicates that (for accreditation) both associate and bachelor degree aviation management programs include a "coherent sequence of business and aviation courses designed to prepare the student to function effectively as a manager in a selected segment of the aviation industry" and that the program "MUST provide focus on a potential career field...such as airlines and airport, or flight operations management or aircraft maintenance management" (Council on Aviation Accreditation, 2003, p. 28).

"Topical Content" for the aviation management specialization includes the type of courses to be included. "Basic Business 
Management” courses recommended include accounting, economics, finance, management, business law, and human resource management. "Management Focused Aviation Course work" describes the type of courses to be offered and provides examples for an air transportation focus. "Providing preparation for a career..." (Council on Aviation Accreditation, 2003, p. 41) is part of the description. This suggests that the discipline of aviation management involves a range of business and management challenges found in the aviation industry.

If there is a common understanding of what aviation management is, and if aviation administration and aviation science (or other terms) are the same thing, that understanding is highly illusive.

\section{Validation}

One of the concepts of natural inquiry (Lincoln \& Guba, 1985) is that sampling need only continue until the results are repetitive. Collecting the above data brought repetitive results. Another basic aspect of research is validation. The data discussed above were reviewed in an education training session on this subject at the 2003 Fall UAA Education Conference. Present during the session were individuals with lengthy and diverse backgrounds in aviation management. The UAA program data was accepted as presented and support was expressed for the process of investigating a definition of aviation management and or defining the pedagogy of aviation management.

\section{Summary}

Here is a recap of what we know about "aviation management" degree programs:

- They started about sixty years ago; probably to provide a four year degree to make pilot students competitive for airline positions.

- At the close of 2003 there were 55 to 60 programs in the United States.

- Departments offering aviation management degrees are assigned to 34 different university "colleges" and "schools" from engineering to business to education to many others.
- These programs offer bachelor degrees with 40 different titles.

- There are about 39 different courses offered by aviation management departments. Half that number are unique courses taught at only one or two schools.

- The primary advertised mission of aviation management programs is to prepare students for jobs in aviation.

- Any written definition of "aviation management" is difficult, if not impossible to find.

\section{A CRITIQUE}

The purpose of these thoughts is to critique, not to criticize. The purpose is to provide perspective for well informed discussions about the future of aviation management programs.

\section{The External Environment}

The President of the United States participated in the Kitty Hawk celebration of the Wright brothers' first flight. Aviation Week \& Space Technology, National Geographic, and The Smithsonian are just a few of the national magazines that had cover stories featuring the anniversary of flight. This symbolizes the strong emotional impact the concept of flight has on the public in general and on many individuals involved in aviation education. This positive emotional attitude toward airplanes and flying is a key cultural norm to be considered when reflecting on the environment in which aviation management education occurs.

A meaningful description of attitudes is found in the conflicting ethnographic portrayal of flight and management. Simultaneous with the first flight celebration television channels were filled with romantic and emotional airplane movies such as The Spirit of St. Louis. If selecting a movie for classroom use to depict human accomplishments in the history and challenge of flight the only difficulty is deciding which one.

Compare this with the challenge of attempting to find a film that accurately portrays the challenge of management in any industry, let alone aviation. (Any suggestions?) As the TV 
stations broadcast great airplane movies the news portrays the foibles of management errors such as the ethics problems at Boeing resulting in a new CEO, and criminal charges placed against several senior officers of major companies. Our cultural environment honors flying and airplanes and does little or nothing to support and frequently criticizes management.

\section{The Educational Environment}

Flight programs were created because of the need to meet the technological advances in aircraft design, manufacture and operation that started in the early 1900s. About the time of World War II a mingling of increased employment standards for pilots and a new series of management related organizational challenges in a growing commercial aviation industry combined to give birth to aviation management degree programs. Aviation management was initially, and perhaps still is, positioned as an off-shoot of flight. It was a logical decision to put aviation management organizationally alongside the program that caused its birth. Flight students continue to be the primary recruits for aviation management bachelor degrees.

Flight education and aviation management are like cojoined twins. The two major fields of study are linked. The degree of connection varies by sets of "twins." At one end of the spectrum are five programs with strongly linked twins. Aviation management students are required to take flight training. (These programs are identified in Table 1.)

Most programs do not require flight training of aviation management students. The other end of the spectrum is Elizabeth City State University. Three Aviation Science degrees are offered with minors in Business Administration, Computer Science or Electronics but the school offers no flight training.

Flying an airplane is seemingly explicitly made more important than managing by two schools. The views are copied from the web pages of departments that offer flight and aviation management majors. The source of the comments is purposefully omitted.

- "Why do some students switch their major to aviation management after being in the flight program? Some (name of school) students switch their majors to Aviation Management because of the cost of the flight program. 's flight program is very challenging and dedication is required for success in the program. ___ 's aviation management degree is an excellent alternative."

A logical conclusion is that being a pilot requires greater dedication and is more challenging than being a manager.

- "Just as all our pilots study aviation management to gain deep insights into their career, those in the management concentration benefit from gaining an understanding the pilot's perspective. We find that managers in the aviation industry are best-equipped and command greater credibility by becoming an aviator."

This seems to say with some assurance that pilots are the best managers in an aviation company. Successful airline chief executive officers Bob Crandall, Herb Kelleher and Stephen Wolf, among others, might disagree.

Based on personal observations made during the UAA Fall 2003 Educational Conference it appears flight related issues have the major emphasis in UAA processes. "Simulators" seems to refer to flight simulators only and cabin, ticket counter, podium, galley or business game simulators are apparently omitted from discussion. Committees exist for flight training and ATC education. The list of all UAA committees includes (University Aviation Association, 2004):

ATC Education

Aviation Education

Awards

Center of Excellence

Curriculum

Distance Learning

Flight Education

Meeting Planning

Membership

National Advisory Council

Publications

Test Advisory

Scholarship

Simulation

Technical Education

Legislative Affairs 
Future Funding Strategies

Safety

NBAA/UAA Professional Development

Program.

There is no committee for aviation management. (On April 15, 2004 the UAA Board agreed to form an Aviation Management Committee [Chubb, 2004].)

It would be interesting to learn the last time the safety committee considered the challenge of educating students about the problems and techniques of educating students on how to reduce occupational injuries among airline office employees, ticket counter and ramp service personnel or flight attendants.

More than half the departments teaching aviation management are located in colleges with some combination of science and technology in the title. Flight training logically fits. But, consider the management challenges facing today's airlines, airports and major aviation equipment suppliers. The success or failure of these companies does not rest on pilot skills or technical and engineering expertise, but on business strategy. If placing aviation management education on a continuum with technical knowledge and skills on one end and business and organizational conceptual skills and knowledge on the other, it belongs well along toward the business end. A respected financial journal states the problem clearly, "...the basic business model of the network carriers is broken, and ... they will have to reinvent themselves or go out of business" (Economist.com, 2004, March25, Airlines under siege, 12). This is clearly a management challenge.

\section{Course Offerings}

The emphasis on flight training and airplanes may breed some misunderstanding of what it is that aviation managers do. For example, what is the product of an airline? Flight and maintenance departments have established a commendable history of providing dependable, risk free operation of the airplane. Senior managers of airlines don't ignore the challenge of maintaining this fine record, but this section of the industry tends not to be the major factor in strategic planning. Marketing issues of price, schedule and frequent flyer programs are what identifies an airline to most customers. Wells and Wensveen state "Why is marketing so important? Without marketing and sales, there would be no airlines” (2004, p. 304).

Michele Burns, speaking as Delta's CFO, views an airline as a big information technology company (Airfinance Journal, 2001). This view makes the key management challenge how communication is mediated. These various perspectives require heavy course emphasis in marketing, business planning, finance, and information technology. No such courses are included in the top ten most frequently offered by aviation management programs.

The largest single employee group at major airlines is the "onboard service" division (alternatively called "inflight service"). Onboard includes hiring, training and managing flight attendants, cabin design including seating configuration, galley design, entertainment systems, supplies (pillows, blankets, headsets, magazines, etc.), food and beverage service and equipment for accidents and incidents such as defibrillators and "first aid" kits, oxygen systems, "safety cards," etc. In 2002 American Airlines employed 102,000 workers (Bureau of Transportation Statistics, 2002), of which 26,000 (Dallas Business Journal, 2003, April 15) or $25 \%$ were flight attendants. Other onboard operational employees and planning and management staff must be added to that number. In spite of this predominant position in the industry, not a single aviation management course is offered that features this aspect of the aviation business.

Anyone who reads the above paragraph and concludes this is a recommendation to train students to become flight attendants is mistaken. There are diverse and complex management challenges in developing, costing, training, monitoring and changing onboard service equipment, procedures and policies. Consider this example from the daily airline operational routine. The next time you are on a commercial flight on which cocktails are sold ask one of the flight attendants to explain how the cash is collected and reported for the liquor and any headset, food, or "duty-free" sales. Look at the accounting process on that one flight and mentally place it as part of a system-wide cash accounting procedure. Then consider how those 
for sale products are chosen, purchased, loaded and stored on the aircraft, what systems exist to prevent loss due to theft, etc? Understanding the need and challenge of managing these types of issues are the type of material to be included in an onboard curriculum.

For a larger challenge, consider changing behavior of the flight attendant employee group. This type of managerial problem is seen in a recent example at American. On March 30, 2004, John Tiliacos, an American Airline regional manager wrote a letter to thousands of flight attendants telling them the negative things customers are saying about their performance (Torbenson, 2004). How does the airline improve customer ratings of flight attendant "friendliness" and or "helpfulness" as measured by passenger surveys and comments? This remains an unanswered management challenge. Aviation management students need to be aware of the problem, and the many causes for the problem, and encouraged to help seek effective solutions.

\section{Summary}

There is no claim made or intended that anything in aviation education is broken and requires an emergency fix! No suggestion is made that aviation management programs abandon their roots and start a mass exodus to business schools. Aviation management being cojoined and working cooperatively with flight (and perhaps aviation maintenance) in a single university administrative organization should provide strength to the entire aviation program. However, this relationship must be treated with caution. There is a tendency for the technology of the physical airplane and piloting “...to create the ways in which people perceive reality" (Postman, 1992, p. 21). The reality of aviation management requires administrators, faculty, alumni and students recognize that management is a process and challenge much different and arguably more complex than flying airplanes.

\section{RECOMMENDATIONS}

These comments are intended as realistic and definitive suggestions to improve the overall performance or effectiveness of UAA aviation management programs. Five recommendations follow. The first four are actions for individuals acting within and as part of an institutional system, especially the UAA. The fifth recommendation is more personal and is addressed to educators, advisory board members and to others not directly involved in the educational process but who consider aviation management important. It is followed by a lengthy explanation.

1. The UAA is encouraged to form an Aviation Management Committee.

2. One of the new committee's first tasks should be an effort to define "aviation management" and create an appropriate pedagogy. This is best accomplished by working closely with the Council on Aviation Accreditation. After creating these concepts the committee can initiate the appropriate academic dialog within the community in an attempt to reach a broad consensus view.

3. Each academic oriented UAA committee is encouraged to determine if aviation management is appropriately balanced within the committee's activities. Should the management aspect of air traffic control (for example) receive additional emphasis?

4. A critical aspect of an academic discipline is both doing research and sharing it. The local campus library or electronic joint library retrieval system available to you and your students has a plethora of management or business journals readily available such as the Harvard Business Review. Determine if your campus library (or library system) has the research journals of aviation management. Examples are Collegiate Aviation Review, Journal of Air Transport Management, Journal of Air Transportation, etc. If not, work to make them available. Aviation management will not and should not be considered a meaningful discipline unless undergraduate and graduate students and faculty - especially new faculty - has ready access to the discipline's historical research efforts. 
5. As an individual educator support the value of student personal achievement in aviation management.

The last recommendation requires explanation. The nature of pilot or maintenance education allows for specific student personal achievement by successfully completing a "check-ride" or trouble-shooting a maintenance challenge. This provides for immediate personal and sometimes, such as participation on an intercollegiate flight team, public satisfaction and recognition. At the end of the day the student can describe to others the success he or she has obtained. Where is the parallel for the aviation management student? Piloting and solving maintenance challenges include tangible technological processes. It's possible to videotape the process. Management is a difficult process to "see" and the results of the process may not be adequately measured except over long periods of time. Successful learning about management processes may be even more difficult to observe and therefore to recognize individual achievement.

Adding to the complexity of this issue is the anti-management perspective which can be viewed in widely available public forums such as Scott Adam's "Dilbert" comics. The challenge to educators to support student success and achievement in aviation management is difficult! But, it was difficult for the Wright brothers to achieve the first successful flight. And, David Neeleman indicates it wasn't easy when he started Jet Blue (Neeleman, 2003).

Some steps for individuals to consider are:

- Aviation history has pilot "heroes" like Lindberg. The same emphasis can be placed on managerial heroes like W. A. Patterson.

- Ensure the local student internship program has a significant management oriented component as well as flight and maintenance.

- Evaluate the balance of guest lecturers invited to campus. Is there an appropriate mix of speakers who are primarily managers along with those clearly in more technical positions?

- Review the department's advisory board. What is the percentage of members who primarily represent the management function?

- Create opportunities for aviation management students to perform related tasks such as a Junior Achievement club (Junior Achievement, 2004). Investigate whether the local airport manager desires some conceptual work accomplished such as reviewing and recommending new or revised polices and regulations.

- Include in aviation management syllabi the critical role and potential value of management. Perhaps in the urgency to (for example) lecture on "decision making processes" we miss explaining the larger view to our students. The first sentence in the book that many credit with starting today's view of management states, "The manager is the dynamic, life-giving element in every business" (Drucker, 1954, p. 3).This perspective must be shared with our students.

As a community of scholars we can and should add to and as necessary modify this list.

\section{CONCLUSION}

This article concentrates on aviation management bachelor degree programs. The data presented provide a current snap-shot of the 55 to 60 programs offered in the United States. Flight and aviation management programs are linked much like cojoined-twins. The degree to which the programs are linked may put too much emphasis on the technical aspects of aviation at the expense of the management aspects. Five recommendations are made to improve the relationship.

The general public, governmental agencies and other businesses all require an effective aviation industry served by healthy airlines, airports and other aviation related organizations. These organizations, and ultimately the public, are dependent on a trinity of successful and healthy flight, maintenance and management educational programs. If any of those three entities is a weak link, the system dies. The aviation academic community must work consciously to make or retain aviation management as a strong link. 


\section{REFERENCES}

Airfinance Journal. (2001). Profits@deltaair. Airfinance Journal Business Yearbook 2001, 39-41.

Alvesson, M., \& Deetz, S. (2000). Doing critical management research. Thousand Oaks, CA: Sage.

Blake, R., \& Moulton, J. (1985). The managerial grid III: The key to leadership excellence. Houston: Gulf.

Bureau of Transportation Statistics. (2002). 2002 Number of Employees for Certificated Carriers Year End Data 2002. Retrieved March 29, 2004, from http://www.bts.gov/oai/ employees/2002emp.html

Bureau of Transportation Statistics. (2004). Transportation Expressions 1996. Retrieved March 29, 2004, from http://www.bts.gov/cgi-bin/btsprod/expr/expr.pl?letter=a

Chubb, G. P. (2004, Summer). Board of Trustees: Reports of midyear meeting. Collegiate Aviation News, 28(3), 3.

Council on Aviation Accreditation. (2003). Accreditation standards manual Form 101. Auburn, AL: CAA.

Dallas Business Journal. (2003, April 15). American’s flight attendants get voting extension. Retrieved March 29, 2004, from http://www.bizjournals.com/dallas/stories/2003/04/14/ daily14.html?page $=2$

Daft, R. L., \& Marcic, D. (2001). Understanding management ( $3^{\text {rd }}$. ed.). Orlando, FL: Harcourt.

Drucker, P. F. (1954). The practice of management. New York: Harper.

Economist.com. (2004, March 25). Airlines under siege: Silver linings, darkening clouds. Retrieved March 30, 2004 from http://www.economist.com/business/

PrinterFriendly.cfm?Story_ID=2535961

Elizabeth City State University (2004). Aviation Science. Retrieved April 12, 2004, from http://www.ecsu.edu/ecsu/acaddept/technology/bs aviation science.htm

Fairbairn, G.R. (1987). Development of aviation management coursework. In W.D. Geibel (Ed.), 1987 Proceedings University Aviation Association Fall Education Conference (pp. 76 - 98). University Aviation Association

Flouris, T.G. (2001). Collegiate aviation programs in a college of business: The challenge of dual accreditation. Paper presented at the Aviation Management Education and Research Conference, Concordia University, Montreal, Canada.

Fossey, E., Harvey, C., McDermott, \& Davidson, L. (2002). Understanding and evaluating qualitative research. Australian and New Zealand Journal of Psychiatry, 36, 717 - 732.

Junior Achievement. (2004). Let their success be your inspiration. Retrieved April 12, 2004 from http://www.ja.org/ 
Kaps, R. W. (1995). Perceptions of aviation professionals and aviation educators concerning industry suggested curriculum content for a non-engineering aviation doctoral degree. Unpublished doctoral dissertation, Southern Illinois University at Carbondale.

Lincoln, Y.S., \& Guba, E.G. (1985). Naturalistic inquiry. Newbury Park, CA: Sage.

Mandis, M.G. (1984). The aero aviation college directory. Fallbrook, CA: Aero.

Neeleman, D. (2003). Welcome from our CEO. Retrieved March 29, 2004, from http://www.jetblue.com/learnmore/index.html

NewMyer, D.A., Kaps, R.W. \& Sigler, J.W. (2001). A review of the scope and status of aviation management degree programs and curricula: What is aviation management? Paper presented at the Aviation Management Education and Research Conference, Concordia University, Montreal, Canada.

Northwestern University. (2003). Northwestern University Transportation Center. Retrieved April 12, 2004, from http://www.nutc.northwestern.edu/public/aboutus/who.html

Oderman, D.B. (2002). Ethics education in university aviation management programs in the US: Part one - the need. Journal of Air Transportation, 7(3), 3-32.

Oderman, D.B. (2003). Ethics education in university aviation management programs in the U.S.: Part two- the current status. Journal of Air Transportation, 8(1), 15-36.

Postman, N. (1992). Technopoly: The surrender of culture to technology. New York: Random House.

St. Louis University. (2004). Parks College of Engineering \& Aviation History. Retrieved March 29, 2004, from http://parks.slu.edu/history.html

Torbenson, E. (2004, April 14). American shares service complaints. DallasNews.com. Retrieved April 14, 2004, from http://www.dallasnews.com/cgi-bi/bi/gold_print.cgi

University Aviation Association. (2004). Committee Chairs. Retrieved April 16, 2004 from http://uaa.auburn.edu/chairs.htm

University of Maryland Eastern Shore. (2004). What are Aviation Sciences? Retrieved April 12, 2004 from http://www.umes.edu/engavi/Sciences.htm

Wells, A.T. \& Wensveen, J.G. (2004). Air transportation: a management perspective. (5 ${ }^{\text {th }}$ ed.). Belmont, CA. Thomson.

Worrels, D.S. (2002). The case method: An enhancement to curriculum in aviation management coursework. The Journal of Aviation/Aerospace Education \& Research, 11(3), 25-32. 
Table 1. University Aviation Association (UAA) Member Schools Offering "Aviation Management" Bachelor Degree Programs

Note: AC - The program is accredited by the Counsel on Aviation Accreditation (CAA).

$\mathrm{M}$ - The aviation department's web site includes a mission statement.

\begin{tabular}{|c|c|c|c|c|}
\hline & $\begin{array}{c}\text { Institution } \\
\text { and Location }\end{array}$ & $\begin{array}{l}\text { College/School for } \\
\text { University Programs }\end{array}$ & Major(s) Offered & $\begin{array}{l}\text { Miscellaneous } \\
\text { Comments }\end{array}$ \\
\hline $\begin{array}{l}1 \\
\mathrm{AC} \\
\end{array}$ & $\begin{array}{l}\text { Arizona State University } \\
\text { Mesa, AZ }\end{array}$ & $\begin{array}{l}\text { College of Technology and } \\
\text { Applied Science }\end{array}$ & $\begin{array}{l}\text { Aeronautical Management } \\
\text { Technology }\end{array}$ & \\
\hline $\begin{array}{l}2 \\
\mathrm{AC}\end{array}$ & $\begin{array}{l}\text { Auburn University } \\
\text { Auburn AL }\end{array}$ & College of Business & Aviation Management & \\
\hline 3 & $\begin{array}{l}\text { Averett University } \\
\text { Danville, VA }\end{array}$ & $\begin{array}{l}\text { New to university status, no } \\
\text { "colleges.” }\end{array}$ & $\begin{array}{l}\text { Aerospace Management } \\
\text { Aerospace Management and } \\
\text { Criminal Justice }\end{array}$ & $\begin{array}{l}\text { One of two } \\
\text { programs that offer a } \\
\text { tie with security }\end{array}$ \\
\hline 4 & $\begin{array}{l}\text { Bowling Green State } \\
\text { University } \\
\text { Bowling Green, OH }\end{array}$ & College of Technology & $\begin{array}{l}\text { Aviation Management and } \\
\text { Operations }\end{array}$ & \\
\hline 5 & $\begin{array}{l}\text { Bridgewater State College } \\
\text { Bridgewater, MA }\end{array}$ & $\begin{array}{l}\text { School of Business and } \\
\text { Aviation Science }\end{array}$ & Aviation Management & \\
\hline 6 & $\begin{array}{l}\text { California State } \\
\text { University } \\
\text { Los Angeles, CA }\end{array}$ & $\begin{array}{l}\text { Department of Technology } \\
\text { College of Engineering }\end{array}$ & $\begin{array}{l}\text { Industrial Technology } \\
\text { (option in Aviation } \\
\text { Administration) }\end{array}$ & \\
\hline $\begin{array}{l}7 \\
\mathrm{AC} \\
\end{array}$ & $\begin{array}{l}\text { Central Missouri State } \\
\text { University } \\
\text { Warrensburg, MO }\end{array}$ & $\begin{array}{l}\text { College of Applied Sciences } \\
\text { and Technology }\end{array}$ & $\begin{array}{l}\text { Flight Operations } \\
\text { Management }\end{array}$ & \\
\hline 8 & $\begin{array}{l}\text { Central Washington } \\
\text { University } \\
\text { Ellensburg, WA }\end{array}$ & $\begin{array}{l}\text { College of Education and } \\
\text { Professional Studies }\end{array}$ & $\begin{array}{l}\text { Flight Technology } \\
\text { (Aviation and Airport } \\
\text { Management }\end{array}$ & \\
\hline 9 & $\begin{array}{l}\text { College of Aeronautics } \\
\text { La Guardia Airport, NY } \\
\text { Flushing, NY }\end{array}$ & & $\begin{array}{l}\text { Airline Management } \\
\text { Airport Management }\end{array}$ & \\
\hline 10 & $\begin{array}{l}\text { Daniel Webster College } \\
\text { Nashua, NH }\end{array}$ & & Aviation Management & \\
\hline $\begin{array}{l}11 \\
M\end{array}$ & $\begin{array}{l}\text { Delaware State University } \\
\text { Dover, DE }\end{array}$ & $\begin{array}{l}\text { School of Professional } \\
\text { Studies }\end{array}$ & $\begin{array}{l}\text { Airway Science } \\
\text { Management }\end{array}$ & \\
\hline $\begin{array}{l}12 \\
M\end{array}$ & $\begin{array}{l}\text { Delta State University } \\
\text { Cleveland, MS }\end{array}$ & College of Business & Aviation Management & \\
\hline 13 & $\begin{array}{l}\text { Dowling College } \\
\text { Oakdale, NY }\end{array}$ & & Aviation Management & \\
\hline $\begin{array}{l}14 \\
M\end{array}$ & $\begin{array}{l}\text { Elizabeth City State } \\
\text { University } \\
\text { Elizabeth City, NC }\end{array}$ & $\begin{array}{l}\text { A department of the } \\
\text { university not assigned to a } \\
\text { college/school. }\end{array}$ & $\begin{array}{l}\text { Aviation Science } \\
\text { (concentration in business } \\
\text { administration) }\end{array}$ & $\begin{array}{l}\text { Does not offer flight } \\
\text { training. } \\
\text { Offers unique Social } \\
\text { Responsibility and } \\
\text { Ethics course. }\end{array}$ \\
\hline
\end{tabular}




\begin{tabular}{|c|c|c|c|c|}
\hline $\begin{array}{l}15 \\
\mathrm{AC}\end{array}$ & $\begin{array}{l}\text { Embry-Riddle } \\
\text { Aeronautical University } \\
\text { Daytona Beach, FL }\end{array}$ & College of Business & $\begin{array}{l}\text { Aviation Business } \\
\text { Administration } \\
\text { Aviation Management }\end{array}$ & \\
\hline 16 & $\begin{array}{l}\text { Fairmont State College } \\
\text { Bridgeport, WV }\end{array}$ & School of Technology & Aviation Administration & \\
\hline $\begin{array}{l}17 \\
\mathrm{AC}\end{array}$ & $\begin{array}{l}\text { Florida Institute of } \\
\text { Technology } \\
\text { Melbourne, FL }\end{array}$ & School of Aeronautics & Aviation Management & \\
\hline 18 & $\begin{array}{l}\text { Florida Memorial College } \\
\text { Miami, FL }\end{array}$ & & $\begin{array}{l}\text { Airway Science } \\
\text { Management }\end{array}$ & $\begin{array}{l}\text { Offers unique } \\
\text { Passenger } \\
\text { Management course. }\end{array}$ \\
\hline 19 & $\begin{array}{l}\text { Georgia State University } \\
\text { Atlanta, GA }\end{array}$ & $\begin{array}{l}\text { Andrew Young School of } \\
\text { Policy Studies }\end{array}$ & $\begin{array}{l}\text { Urban Policy Studies } \\
\text { (specialization in aviation } \\
\text { management) }\end{array}$ & \\
\hline 20 & $\begin{array}{l}\text { Hampton University } \\
\text { Hampton, VA }\end{array}$ & $\begin{array}{l}\text { School of Engineering and } \\
\text { Technology }\end{array}$ & Aviation Management & \\
\hline 21 & $\begin{array}{l}\text { Henderson State } \\
\text { University } \\
\text { Arkadelphia, AR }\end{array}$ & School of Business & Airway Science & $\begin{array}{l}\text { Requires pilot } \\
\text { training. }\end{array}$ \\
\hline 22 & $\begin{array}{l}\text { Indiana State University } \\
\text { Terre Haute, IN }\end{array}$ & School of Technology & Aerospace Administration & \\
\hline 23 & $\begin{array}{l}\text { Jacksonville University } \\
\text { Jacksonville, FL }\end{array}$ & Davis College of Business & $\begin{array}{l}\text { Aviation Management } \\
\text { Aviation Management and } \\
\text { Flight Operations }\end{array}$ & $\begin{array}{l}\text { Offers unique } \\
\text { Executive } \\
\text { Communication } \\
\text { Techniques course. }\end{array}$ \\
\hline 24 & $\begin{array}{l}\text { Kent State University } \\
\text { Kent, OH }\end{array}$ & School of Technology & Aviation Management & \\
\hline 25 & $\begin{array}{l}\text { Lewis University } \\
\text { Romeoville, IL }\end{array}$ & $\begin{array}{l}\text { College of Arts and } \\
\text { Sciences }\end{array}$ & Aviation Administration & \\
\hline $\begin{array}{l}26 \\
\text { AC }\end{array}$ & $\begin{array}{l}\text { Louisiana Tech } \\
\text { University } \\
\text { Ruston, LA }\end{array}$ & College of Liberal Arts & Aviation Management & \\
\hline $\begin{array}{l}27 \\
M\end{array}$ & $\begin{array}{l}\text { Lynn University } \\
\text { Boca Raton, FL }\end{array}$ & $\begin{array}{l}\text { Morgan School of } \\
\text { Aeronautics }\end{array}$ & $\begin{array}{l}\text { Business Administration } \\
\text { (specialization in Aviation } \\
\text { Management) }\end{array}$ & \\
\hline 28 & $\begin{array}{l}\text { Marywood University } \\
\text { Scranton, PA }\end{array}$ & $\begin{array}{l}\text { College of Creative Arts } \\
\text { and Management }\end{array}$ & $\begin{array}{l}\text { Business Administration } \\
\text { (Airport/Airline } \\
\text { Management track) }\end{array}$ & $\begin{array}{l}\text { Requires pilot } \\
\text { training. }\end{array}$ \\
\hline 29 & $\begin{array}{l}\text { Metropolitan State } \\
\text { College of Denver } \\
\text { Denver, CO }\end{array}$ & $\begin{array}{l}\text { School of Professional } \\
\text { Studies }\end{array}$ & Aviation Management & $\begin{array}{l}\text { Appears to require a } \\
\text { Flight Dispatch and } \\
\text { Load Planning } \\
\text { course. }\end{array}$ \\
\hline $\begin{array}{l}30 \\
\text { AC }\end{array}$ & $\begin{array}{l}\text { Middle Tennessee State } \\
\text { University } \\
\text { Murfreesboro, TN }\end{array}$ & $\begin{array}{l}\text { College of Basic and } \\
\text { Applied Science }\end{array}$ & $\begin{array}{l}\text { Aerospace (concentration in } \\
\text { Administration) }\end{array}$ & \\
\hline
\end{tabular}




\begin{tabular}{|c|c|c|c|c|}
\hline 31 & $\begin{array}{l}\text { Minnesota State } \\
\text { University } \\
\text { Mankato, MN }\end{array}$ & College of Education & $\begin{array}{l}\text { Aviation (concentration in } \\
\text { Aviation Management) }\end{array}$ & $\begin{array}{l}\text { Requires pilot } \\
\text { training. }\end{array}$ \\
\hline 32 & $\begin{array}{l}\text { The Ohio State University } \\
\text { Columbus, OH }\end{array}$ & $\begin{array}{l}\text { College of Arts and Science, } \\
\text { and } \\
\text { College of Engineering }\end{array}$ & $\begin{array}{l}\text { BA Aviation (Aviation } \\
\text { Management) }\end{array}$ & \\
\hline 33 & $\begin{array}{l}\text { Ohio University } \\
\text { Albany, OH }\end{array}$ & $\begin{array}{l}\text { College of Education and } \\
\text { Technology }\end{array}$ & $\begin{array}{l}\text { Aviation Sciences (Aviation } \\
\text { Management option) }\end{array}$ & \\
\hline 34 & $\begin{array}{l}\text { Oklahoma State } \\
\text { University } \\
\text { Stillwater, OK Tulsa, OK }\end{array}$ & College of Education & $\begin{array}{l}\text { BS in Aviation Sciences } \\
\text { (Aviation Management) }\end{array}$ & \\
\hline AC & $\begin{array}{l}\text { Purdue University } \\
\text { W. Lafayette, IN }\end{array}$ & School of Technology & $\begin{array}{l}\text { Aviation Administration } \\
\text { Technology }\end{array}$ & $\begin{array}{l}\text { Only program that } \\
\text { has reference to } \\
\text { airport service } \\
\text { industries. }\end{array}$ \\
\hline 36 & $\begin{array}{l}\text { Rocky Mountain College } \\
\text { Billings, MT }\end{array}$ & & Aviation Management & \\
\hline 37 & $\begin{array}{l}\text { San Jose State University } \\
\text { San Jose, CA }\end{array}$ & College of Engineering & $\begin{array}{l}\text { Aviation Operations } \\
\text { (concentration in } \\
\text { Administration) } \\
\end{array}$ & \\
\hline 38 & $\begin{array}{l}\text { Southeastern Oklahoma } \\
\text { State University } \\
\text { Durant, OK }\end{array}$ & Aviation Science Institute & $\begin{array}{l}\text { Aviation Management } \\
\text { (options in (1) business, (2) } \\
\text { safety, or (3) security) }\end{array}$ & $\begin{array}{l}\text { One of two schools } \\
\text { that offer a tie with } \\
\text { security issues. }\end{array}$ \\
\hline 39 & $\begin{array}{l}\text { Southern Illinois } \\
\text { University } \\
\text { Carbondale, IL }\end{array}$ & $\begin{array}{l}\text { College of Applied Science } \\
\text { and Arts }\end{array}$ & Aviation Management & \\
\hline 40 & $\begin{array}{l}\text { St. Cloud State University } \\
\text { St. Cloud, MN }\end{array}$ & $\begin{array}{l}\text { College of Science and } \\
\text { Engineering }\end{array}$ & $\begin{array}{l}\text { Aviation (emphasis in } \\
\text { management or operations) }\end{array}$ & $\begin{array}{l}\text { Unique Women in } \\
\text { Aviation course. }\end{array}$ \\
\hline 41 & $\begin{array}{l}\text { St. Francis College } \\
\text { Brooklyn Heights, NY }\end{array}$ & & $\begin{array}{l}\text { Aviation Administration } \\
\text { Aviation Business Studies }\end{array}$ & $\begin{array}{l}\text { Only program to } \\
\text { offer a series of } \\
\text { courses on travel and } \\
\text { tourism. }\end{array}$ \\
\hline AC & $\begin{array}{l}\text { St. Louis University } \\
\text { St. Louis, MO }\end{array}$ & $\begin{array}{l}\text { Parks College of } \\
\text { Engineering \& Aviation }\end{array}$ & $\begin{array}{l}\text { Aeronautics } \\
\text { Aviation Science/Aviation } \\
\text { Management }\end{array}$ & \\
\hline 43 & $\begin{array}{l}\text { State University of New } \\
\text { York } \\
\text { Farmingdale, NY }\end{array}$ & $\begin{array}{l}\text { School of Engineering } \\
\text { Technologies }\end{array}$ & $\begin{array}{l}\text { Aviation Administration } \\
\text { (cargo specialization) }\end{array}$ & $\begin{array}{l}\text { Only program that } \\
\text { specializes in cargo } \\
\text { management. }\end{array}$ \\
\hline 44 & $\begin{array}{l}\text { Tarleton State University } \\
\text { Killeen, TX }\end{array}$ & $\begin{array}{l}\text { College of Science and } \\
\text { Technology }\end{array}$ & $\begin{array}{l}\text { Aviation Science (Aviation } \\
\text { Management option) }\end{array}$ & $\begin{array}{l}\text { Program designed to } \\
\text { only accept those } \\
\text { with two prior years } \\
\text { of study typically in } \\
\text { a flight program. }\end{array}$ \\
\hline 45 & $\begin{array}{l}\text { Tennessee State } \\
\text { University } \\
\text { Nashville, TN }\end{array}$ & $\begin{array}{l}\text { College of Engineering, } \\
\text { Technology and Computer } \\
\text { Science }\end{array}$ & $\begin{array}{l}\text { Aeronautical and Industrial } \\
\text { Technology (concentration } \\
\text { in Aviation Management ) }\end{array}$ & \\
\hline
\end{tabular}




\begin{tabular}{|c|c|c|c|c|}
\hline 46 & $\begin{array}{l}\text { Texas Southern } \\
\text { University } \\
\text { Houston, TX }\end{array}$ & $\begin{array}{l}\text { Department of } \\
\text { Transportation, } \\
\text { College of Science and } \\
\text { Technologies }\end{array}$ & $\begin{array}{l}\text { Airway Science } \\
\text { Management }\end{array}$ & $\begin{array}{l}\text { Offers a course that } \\
\text { combines FBO and } \\
\text { aviation service } \\
\text { operations. }\end{array}$ \\
\hline 47 & $\begin{array}{l}\text { University of Alaska } \\
\text { Anchorage, AK }\end{array}$ & $\begin{array}{l}\text { Aviation Technology } \\
\text { Division }\end{array}$ & $\begin{array}{l}\text { Aviation Administration - } \\
\text { Aviation Management }\end{array}$ & \\
\hline 48 & $\begin{array}{l}\text { University of Dubuque } \\
\text { Dubuque, IA }\end{array}$ & $\begin{array}{l}\text { School of Professional } \\
\text { Programs }\end{array}$ & Aviation Management & $\begin{array}{l}\text { Offers a Safety and } \\
\text { Ethics in Aviation } \\
\text { course, and a } \\
\text { scheduling course. }\end{array}$ \\
\hline 49 & $\begin{array}{l}\text { University of Louisiana } \\
\text { Monroe, LA }\end{array}$ & $\begin{array}{l}\text { College of Arts and } \\
\text { Sciences }\end{array}$ & Aviation Administration & \\
\hline $\begin{array}{l}50 \\
M\end{array}$ & $\begin{array}{l}\text { University of Maryland } \\
\text { Eastern Shore } \\
\text { Princess Anne, MD }\end{array}$ & $\begin{array}{l}\text { School of Business and } \\
\text { Technology }\end{array}$ & $\begin{array}{l}\text { Aviation Science } \\
\text { (concentration in Aviation } \\
\text { Management) }\end{array}$ & \\
\hline 51 & $\begin{array}{l}\text { University of Nebraska } \\
\text { Kearney, NE }\end{array}$ & $\begin{array}{l}\text { College of Business and } \\
\text { Technology }\end{array}$ & $\begin{array}{l}\text { Aviation Science } \\
\text { Management (options from } \\
\text { either the Business School }\end{array}$ & \\
\hline $\begin{array}{l}52 \\
\mathrm{AC}\end{array}$ & $\begin{array}{l}\text { University of Nebraska } \\
\text { Omaha, NE }\end{array}$ & $\begin{array}{l}\text { College of Public Affairs } \\
\text { and Community Service }\end{array}$ & $\begin{array}{l}\text { Public Administration } \\
\text { (specialization in Aviation } \\
\text { Administration) }\end{array}$ & $\begin{array}{l}\text { Offers Diversity in } \\
\text { Aviation course. }\end{array}$ \\
\hline $\begin{array}{l}53 \\
\text { AC }\end{array}$ & $\begin{array}{l}\text { University of North } \\
\text { Dakota } \\
\text { Grand Forks, ND }\end{array}$ & $\begin{array}{l}\text { School of Aerospace } \\
\text { Sciences }\end{array}$ & $\begin{array}{l}\text { Aviation Management } \\
\text { Airport Management }\end{array}$ & $\begin{array}{l}\text { Offers unique } \\
\text { Methods and } \\
\text { Materials in } \\
\text { Teaching Aviation } \\
\text { course. } \\
\text { Requires pilot } \\
\text { training. }\end{array}$ \\
\hline 54 & $\begin{array}{l}\text { University of Oklahoma } \\
\text { Department of Aviation } \\
\text { Norman, OK }\end{array}$ & $\begin{array}{l}\text { College of Continuing } \\
\text { Education }\end{array}$ & Aviation Management & $\begin{array}{l}\text { Requires pilot } \\
\text { training. }\end{array}$ \\
\hline AC & $\begin{array}{l}\text { Western Michigan } \\
\text { University } \\
\text { Battle Creek, MI }\end{array}$ & College of Aviation & $\begin{array}{l}\text { Aviation Science and } \\
\text { Administration }\end{array}$ & \\
\hline 56 & $\begin{array}{l}\text { Westminster College } \\
\text { Salt Lake City, UT }\end{array}$ & & Aviation Management & \\
\hline
\end{tabular}


Table 2. Aviation Management Degree Titles Offered at UAA Member Schools

\begin{tabular}{|c|c|c|}
\hline & Degree Title & $\begin{array}{c}\text { Number of } \\
\text { duplicate } \\
\text { titles }\end{array}$ \\
\hline 1 & $\begin{array}{l}\text { Aeronautical and Industrial Technology (concentration in Aviation } \\
\text { Management) }\end{array}$ & \\
\hline 2 & Aeronautical Management Technology & \\
\hline 3 & Aeronautics & \\
\hline 4 & Aerospace (concentration in Administration) & \\
\hline 5 & Aerospace Administration & \\
\hline 6 & Aerospace Management & \\
\hline 7 & Aerospace Management and Criminal Justice & \\
\hline 8 & Aerospace Studies & \\
\hline 9 & Airline Management & \\
\hline 10 & Airport Management & 2 \\
\hline 11 & Airway Science & \\
\hline 12 & Airway Science Management & 2 \\
\hline 13 & Aviation (Aviation Management) & \\
\hline 14 & Aviation (emphasis in management or operations) & \\
\hline 15 & Aviation Administration & 3 \\
\hline 16 & Aviation Administration - Aviation Management & \\
\hline 17 & Aviation Administration (cargo specialization) & \\
\hline 18 & Aviation Administration Technology & \\
\hline 19 & Aviation Business Administration & \\
\hline 20 & Aviation Business Studies & \\
\hline 21 & Aviation Management & 18 \\
\hline 22 & Aviation Management (options in (1) business, (2) safety, or (3) security) & \\
\hline 23 & Aviation Management and Flight Operations & \\
\hline 24 & Aviation Management and Operations & \\
\hline 25 & Aviation Operations (concentration in Administration) & \\
\hline 26 & Aviation Science (Aviation Management option) & \\
\hline 27 & Aviation Science (concentration in Aviation Management) & \\
\hline 28 & Aviation Science (concentration in business administration) & \\
\hline 29 & Aviation Science and Administration & \\
\hline 30 & Aviation Science Management & \\
\hline 31 & Aviation Science/Aviation Management & \\
\hline 32 & Aviation Sciences (Aviation Management option) & \\
\hline 33 & Aviation Sciences (Aviation Management) & \\
\hline 34 & Business Administration (Airport/Airline Management track) & \\
\hline 35 & Business Administration (specialization in Aviation Management) & \\
\hline 36 & Flight Operations Management & \\
\hline 37 & Flight Technology (Aviation and Airport Management Specialization) & \\
\hline 38 & Industrial Technology (option in Aviation Administration) & \\
\hline 39 & Public Administration (specialization in Aviation Administration) & \\
\hline 40 & Urban Policy Studies (specialization in aviation management) & \\
\hline
\end{tabular}


Table 3. Administrative Placement of Departments Offering Aviation Management Degrees in University "Colleges" and "Schools"

\begin{tabular}{|c|l|c|}
\hline \multicolumn{1}{|c|}{ Name of College or School } & $\begin{array}{c}\text { Repetitive } \\
\text { Placements }\end{array}$ \\
\hline 1 & Aviation Science Institute & \\
\hline 2 & Aviation Technology Division & \\
\hline 3 & College of Applied Sciences and Arts & 3 \\
\hline 4 & College of Arts and Science & \\
\hline 5 & College of Aviation & 4 \\
\hline 6 & College of Basic and Applied Science & \\
\hline 7 & College of Business & \\
\hline 8 & College of Business and Technology & \\
\hline 9 & College of Continuing Education & \\
\hline 10 & College of Creative Arts and Management & 3 \\
\hline 11 & College of Education & \\
\hline 12 & College of Education and Technology & \\
\hline 13 & College of Engineering & \\
\hline 14 & College of Engineering \& Aviation & \\
\hline 15 & College of Engineering, Technology and Computer Science & \\
\hline 16 & College of Liberal Arts & \\
\hline 17 & College of Public Affairs and Community Service & \\
\hline 18 & College of Science and Engineering & \\
\hline 19 & College of Science and Technologies & \\
\hline 20 & College of Science and Technology & \\
\hline 21 & College of Technology & \\
\hline 22 & College of Technology and Applied Science & \\
\hline 23 & None - university program not in a college/school & \\
\hline 24 & School of Aeronautics & \\
\hline 25 & School of Aerospace Sciences & \\
\hline 26 & School of Business & \\
\hline 27 & School of Business and Aviation Science & \\
\hline 28 & School of Business and Technology & \\
\hline 29 & School of Engineering and Technology & \\
\hline 30 & School of Engineering Technologies & \\
\hline 31 & School of Policy Studies & \\
\hline 32 & School of Professional Programs & \\
\hline 33 & School of Professional Studies & \\
\hline 34 & School of Technology & \\
\hline & & \\
\hline
\end{tabular}


Table 4. Courses Included in Aviation Management Curricula

A. Top-ten courses taught in aviation management programs (NewMyer, Kaps \& Sigler, 2001).

\begin{tabular}{|c|l|}
\hline 1 & Aviation Law \\
\hline 2 & Aviation Safety \\
\hline 3 & Airline Management \\
\hline 4 & Airport Management \\
\hline 5 & Basic Air Traffic Control \\
\hline 6 & Air Transportation \\
\hline 7 & Current Aviation Management Practices \\
\hline 8 & Airport Planning and Design \\
\hline 9 & Human Factors/Crew Resource Management \\
\hline 10 & Aviation Management Writing and Communication \\
\hline
\end{tabular}

B. Other courses taught in three or more programs.

\begin{tabular}{|l|l|}
\hline 11 & Aviation History \\
\hline 12 & Air transport research \\
\hline 13 & Aviation Regulations \\
\hline 14 & Cargo operations \\
\hline 15 & Corporate/business Aviation Operations \\
\hline 16 & Fixed Base/Airport Services/Fueling Operations \\
\hline 17 & General Aviation Operations \\
\hline 18 & International Airline Operations \\
\hline 19 & Marketing \\
\hline 20 & National Aviation Policy \\
\hline 21 & Regional Jet/Commuter Operations \\
\hline
\end{tabular}

C. Unique courses taught in one or two programs.

\begin{tabular}{|l|l|}
\hline 22 & Air Transportation Logistics \\
\hline 23 & Aviation Insurance/Risk Management \\
\hline 24 & Diversity in Aviation \\
\hline 25 & Executive Communication Techniques \\
\hline 26 & Impact of Aviation and Space Exploration on Society \\
\hline 27 & Intermodal Transportation \\
\hline 28 & Management Decision Making \\
\hline 29 & Methods and Materials in Teaching Aviation \\
\hline 30 & Passenger Traffic Management \\
\hline 31 & Safety and Ethics in Aviation \\
\hline 32 & Scheduling (aircraft, crew and services) \\
\hline 33 & Social Responsibility and Ethics \\
\hline 34 & Taxes \\
\hline 35 & Telecommunications \\
\hline 36 & The Travel Industry \\
\hline 37 & Tourism Development \\
\hline 38 & Travel and Economic Geography \\
\hline 39 & Women in Aviation \\
\hline
\end{tabular}

